SECTION I 



\title{
A Note on Durkheim's Creation of Les Formes Élémentaires
}

\author{
W. Watts Miller
}

It is just a basic point that a help with understanding a work is to understand something about the process of its creation. In the case of Les formes élémentaires, it is evident from the lecture-course reading like a first draft of the work, and begun in 1906 (1907f), that the project started life as a concern, above all, with the study of early elementary religion. But even here, the logic of Durkheim's argument - especially in his critique of animist and naturist theories of early religion - required him to make claims about basic elemental characteristics of all religion. And it is evident from correspondence of 1908, as well as from an article he started to write the same year and got published the following year (1909d), that the project had converted into a concern, above all, with a way to get at and understand basic continuing elemental forms of all religion.

The manuscript was finished in 1911, and emerged from the printers in the summer of 1912. But even after the completion of the text, the author in a way continued to create the work, in the activity of going around explaining what it was above all about. And this is why it is so significant that, in each and every case of the four recorded occasions in which he did this, he emphasizes how his new book is about the 'dynamogenic' character of religion - significant, because as he makes crystal clear, this a key universal and elemental characteristic of all religion.

So in sum, it was through exploring the creation of Les formes élémentaires, that it was suggested it was time to end its career as a museum exhibit of $19^{\text {th }}$ century theories of early elementary religion, and to renew its life as Elemental Forms of all religion (Watts Miller 2005).

Of course, it is possible to reach this conclusion through an internal analysis of the actual published text. Indeed, it is precisely the conclusion argued for by Karen Fields in her introduction to what has now become the established English translation (Fields 1995: lix-lx). And apart from the importance of a collective division of labour in the use of different methods to approach a work, a fundamental problem isn't so much how to translate Les formes élémentaires, as how to understand and interpret it in the first place. Durkheim can be quite baffling to the modern French reader - a point 
made elsewhere in this issue by Raymond Boudon (2006), and one of his examples is dynamogénique itself.

Nonetheless, there is still the question of translation. As Karen Fields writes, her introduction of over a decade ago:

made the case that the title Elemental Forms would have invited less misunderstanding among English-speaking readers than Elementary Forms has done, and argued that the distinction provides a key to the overall project of Durkheim's masterpiece. (Fields 2006, personal communication)

This hits the nail on the head. And, after all, an important part of the work's life, career and collective creation has been its life, career and collective creation - ever since Joseph Swain's first very early translation in 1915 - as The Elementary Forms. But also, a reason for wanting to say goodbye to all that, and to campaign for the work's concern with Elemental Forms, again turns up in Raymond Boudon's review-article in this issue, 'Nouveau Durkheim? Vrai Durkheim?' As he brings out, a problem with fashionable 'culturalist' readings is a tendency to over-relativize Durkheim, and to suppress the universalism inherent in his search to understand basic elemental forms of all religious (and indeed, social) life. Indeed, it is a more or less inevitable consequence of their suppression of Durkheim's interest in underlying social relations, structures and dynamics - brought out in another critique in this issue, by Frank Pearce (2006).

\section{The Case of Effervescence}

One of the things that struck me, while on the unsuccessful hunt for references to the 'dynamogenic' among Durkheim's group before the publication of his masterpiece, was the standard use of terms such as surexcitation and excitation extraordinaire. This then tempted me to suggest that, just as he suddenly hit on the 'dynamogenic' in the launch of his new book, there was an effervescence of effervescence in the actual creative process of writing it up. And it had significance as a way to communicate an idea that had been around among the group for some time by flagging up and publicizing it with a new identifiably Durkheimian brand name - a sort of totem, in fact.

However, this overlooks the occurrence not only of suractivité but effervescence in the conclusion to Mauss's, 'Seasonal Variations in Eskimo Societies' (1906: 125), pointed out by Nick Allen (1998: 157). And it also overlooks the occurrence of effervescence in a review by Durkheim himself (1905a(ii) (2): 382), unearthed by the great detective of Durkheimian Studies, W. S. F. Pickering (1984: 382).

A first point is that these come just before the lecture-course reading like a first draft of the eventual masterpiece and begun in 1906, but in which there isn't any talk of effervescence, merely of paroxysme and an exaltation à un degré extraordinaire (1907f: 96). A next point is that Durkheim wasn't 
in any position to get on with his eventual masterpiece until getting over some shock news from Australia. This stuck a bomb under his whole armchair anthropologist's idea of early elementary religion and society. And the shock news first reached Paris through Spencer and Gillen's The Native Tribes of Central Australia (1899), then arrived in a second instalment in their Northern Tribes of Central Australia (1904). It is why any assessment of Durkheim's 'Australia' is difficult without reading both these works, complete with their photographs and wonderful reproductions, in colour, of Australian art. It is why his eventual work's references to Spencer and Gillen far outnumber any others - a point made en passant by another great detective in Durkheimian Studies, Massimo Borlandi (1993: 68). And it is why, between 1900 and 1905, Durkheim and Mauss spent a lot of time trying to work out a response to Spencer and Gillen in the pages of the Année sociologique. In my own view, what happened was that Durkheim spent his time on long laborious expeditions into what, from the perspective of his eventual masterpiece, were essentially dead-ends. It was his nephew who, more or less from the beginning, intuitively glimpsed the most promising route ahead. But was it thanks to the nephew that the uncle at last saw the light? Or was it was it thanks to the uncle's own effort, in his own way, to sort things out? It is clear from their correspondence that their collaboration involved its difficulties - for example, they had to share a single copy of Spencer and Gillen as well as of other books, with frequent irritated avuncular requests to the nephew for their return. It is nonetheless evident that it was a close working collaboration, that there was an indispensably collective, group creation of Les formes élémentaires, and that Durkheim wasn't altogether generous in his acknowledgement of this, as noted by Nick Allen (1998: 157).

In any case, there is an important difference between the occurrence of effervescence in Mauss's essay and in Durkheim's review. In the essay:

Winter is a season when the society, strongly concentrated, is in a continuous state of effervescence and hyperactivity. (Mauss 1906: 125)

So this corresponds with the theme, in Les formes élémentaires, of different alternating energies, rhythms, durations and stretches of time as a universal of socially lived and experienced time (in an implicit contrast with a modern pathological regime of 'clock time'). In the review, and in a comment on the French Revolution:

The effervescence and collective enthusiasm that characterized this creative era necessarily came to take on, thanks to their very intensity, a religious character. (Durkheim 1905a(ii) (2): 382)

So this corresponds with the concern with great, historically fundamental and creative periods of effervescence. But it is also a concern that can be traced back to another review, again on the French Revolution, and in a comment on its upsurge of idealism: 
It is found in all creative eras, in all times of a new and audacious faith. (Durkheim 1890a: 224)

And I will be rash enough to suggest that this is the first appearance, anywhere in Durkheim's work, of a recognizable nucleus and germ of the whole idea of collective creative effervescence.

It is just that he doesn't do anything with it. The Division of Labour doesn't end with a vision of a whole new eruption of faith. It ends with a call to rebuild morality. And, as The Division of Labour's projected companion volume would have revealed, the way to rebuild morality is through the guild socialism of a network of new occupational groups.

Yet what happened to his project for a companion volume on these? To cut a long story short, the text we have to go on for his course on occupational ethics was written up in 1898-1900 - ironically enough just before The Division of Labour's new preface, written in 1901, and abandoning the project of a companion volume. But in both these texts, whatever might have been the role of religion in the traditional occupational group, it doesn't in fact feature in his vision of the future. On the contrary, the way to social and moral reform isn't through a new faith. It is through a new guild socialism.

True, it was also just around this time that the shock news from Australia helped to take Durkheim along the road that led to The Elemental Forms. But it isn't as if all became clear in this. It is shot through with ambivalence.

The French Revolution is again a test case, turning up in the work's whole centrepiece on effervescence. On the one hand, the Revolution created a new religion, complete with its own dogma, altars, symbols and festivals. On the other, it is a first historical instance of 'a society and its essential ideals becoming the object, directly and without transfiguration of any kind, of a genuine cult' (1912a: 306).

So right at the heart of The Elemental Forms - and as in The Division of Labour - we find a modern secular rationalist ideal of transparence. Of course, it might seem desperate to want a transparent faith. It is like wanting religion without myth, symbolism without opacity, and the sacred without transfiguration. But the trouble with any 'culturalist' or other reading is if it just eliminates or waters down and trivializes what is actually there, built into the text - a fundamental ambivalence between a sociology of transparence and a sociology of transfiguration.

\section{References}

Allen, N. J. 1998 'Effervescence and the origins of human society', in N. J. Allen, W. S. F. Pickering and W. Watts Miller, eds., On Durkheim's Elementary Forms of Religious Life, London: Routledge: 149-161. 
Borlandi, M. 1993 'Durkheim lecteur de Spencer', in Ph. Besnard, M. Borlandi and P. Vogt, eds., Division du travail et lien social. Durkheim un siècle après, Paris: PUF: 67-109.

Boudon, R. 2006 'Nouveau Durkheim? Vrai Durkheim?', Durkheimian Studies / Etudes durkheimiennes, n.s. 12: 137-150.

Durkheim, E. 1890a 'Les principes de 1789 et la sociologie', in Durkheim 1970a: 215-225.

1905a(ii)(2) Review of Pellison, La sécularisation de la morale au XVIII siècle, Année sociologique, 8: 381-382.

1907f 'La religion: origines', in Durkheim 1975b, II: 65-122. 1909d 'Sociologie religieuse et théorie de la connaissance', Revue de métaphysique et de morale 17: 733-758.

1912a Les formes élémentaires de la vie religieuse, Paris: Alcan. 1970a La science sociale et l'action, ed. A. Cuvillier, Paris: Vrin. 1975b Textes, 3 vols., ed. V. Karady, Paris: Minuit.

Fields, K. 1995 'Translator's Introduction: Religion as an Eminently Social Thing', in E. Durkheim, The Elementary Forms of Religious Life, New York: The Free Press: xvii-lxxiii.

Mauss, M. 1906 'Essai sur les variations saisonnières des sociétés eskimos. Essai de morphologie sociale', Année sociologique, 9: 38-132.

Pearce, F. 2006 'A Modest Companion to Durkheim', Durkheimian Studies / Etudes durkheimiennes, n.s. 12: 151-162.

Pickering, W. S. F. 1984 Durkheim's Sociology of Religion, Themes and Theories, London: Routledge \& Kegan Paul.

Spencer, B. and F. J. Gillen 1899 The Native Tribes of Central Australia, London: Macmillan. 1904 The Northern Tribes of Central Australia, London: Macmillan.

Watts Miller, W. 2005 'Dynamogénique and Élémentaire', Durkheimian Studies / Etudes durkheimiennes, n.s. 11: 18-32. 